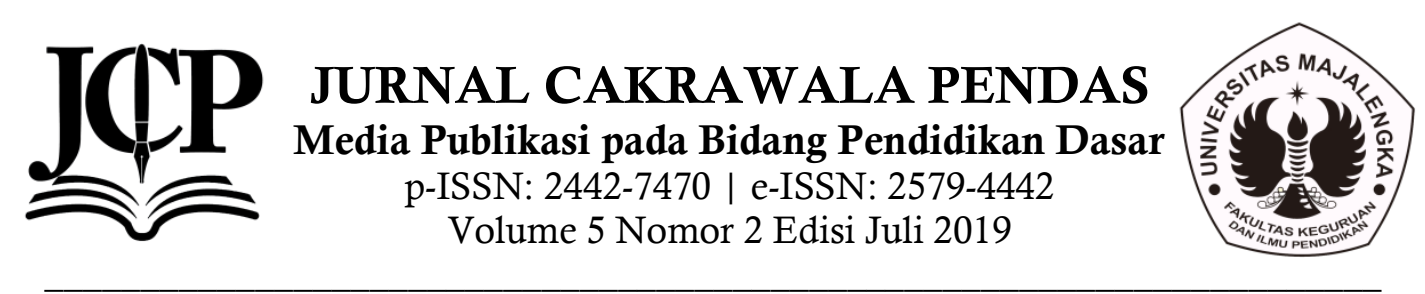

\title{
PENGEMBANGAN BAHAN AJAR BAHASA INDONESIA BERBASIS KONTEKSTUAL UNTUK SISWA KELAS V SEKOLAH DASAR
}

\author{
Hany Uswatun Nisa \\ uswatunhanynisa@gmail.com \\ Pendidikan Bahasa Indonesia, Fakultas Keguruan dan Ilmu Pendidikan, Universitas Muhadi \\ Setiabudi, Jawa tengah
}

\begin{abstract}
Abstrak
Penelitian ini dilatarbelakangi oleh masih banyak guru yang belum memaksimalkan pembelajaran seperti mengembangkan bahan pembelajaran yang dibutuhkan. Bahan ajar berupa buku teks merupakan salah satu media yang memiliki peran penting dalam meningkatkan kualitas pendidikan. Metode penelitian ini menggunakan penelitian dan pengembangan dengan prosedur penelitian yaitu (1) analisis kebutuhan, (2) Pengembangan bahan ajar (3) validasi bahan ajar yang telah dikembangkan. Hasil tes keterbacaan dari bahan ajar ini juga menunjukkan bahwa kriteria keterbacaan mudah dipahami dengan nilai rata-rata siswa menjadi $88 \%$. Berdasarkan paparan penelitian yang telah dilakukan, pengembangan materi pembelajaran bahasa Indonesia di kelas V Sekolah dasar berbasis kontekstual dinyatakan valid.
\end{abstract}

Kata kunci: Bahan Ajar, Kontekstual

\begin{abstract}
This research is motivated by many teachers who have not maximized learning such as developing needed learning materials. Teaching materials in the form of text books are one of the media that have an important role in improving the quality of education. This research method uses research and development with research procedures, namely (1) needs analysis, (2) Development of teaching materials (3) validation of teaching materials that have been developed. The readability test results from this teaching material also show that the criteria for readability are easily understood with the average student score being 88\%. Based on the exposure of the research that has been carried out, the development of Indonesian language learning material in junior high school class VIII based on context is declared valid.
\end{abstract}

Keywords: Teaching Materials, contextual 


\section{Pendahuluan}

Bahasa memiliki peran sentral bagi perkembangan intelektual, sosial, dan emosional peserta didik dan merupakan penunjang keberhasilan dalam mempelajari semua bidang studi lainya. Hakikat bahasa secara umum adalah alat untuk menyampaikan pesan yang terlintas di dalam hati dan pikiran manusia. Lebih jauh lagi bahasa adalah alat untuk berkomunikasi dan berinteraksi, dalam artian alat untuk menyampaikan pikiran, gagasan, konsep serta perasaan. Sejalan dengan hal tersebut menurut Kridalaksana (Chaer, 2013, p32) bahasa adalah sistem lambang bunyi yang arbiter yang digunakan oleh para anggota kelompok sosial untuk bekerja sama berkomunikasi, dan mengidentifikasi diri. Penjelasan tersebut semakin menegaskan bahwa bahasa adalah alat komunikasi yang digunakan baik secara individu ataupun secara kelompok.

Bahasa yang digunakan oleh negara Indonesia adalah bahasa Indonesia, yang telah ditetapkan dalam UUD 1945 pasal 36 (Silvia, 2010, p52) bahwa bahasa negara adalah bahasa Indonesia. Oleh sebab itu pembelajaran bahasa Indonesia diajarkan pada semua jenjang pendidikan mulai dari Sekolah Dasar sampai dengan Perguruan Tinggi, yang diarahkan untuk meningkatkan kemampuan peserta didik untuk berkomunikasi dalam bahasa Indonesia dengan baik dan benar, baik secara lisan maupun tulis. Selain hal tersebut bahasa Indonesia memiliki hakikat sebagai bahasa pengantar dalam pendidikan nasional (saleh, 2015) Mengenai hakikat bahasa Indonesia dalam kehidupan berbangsa dan bernegara, bahasa Indonesia berfungsi, antara lain sebagai bahasa resmi negara, bahasa pengantar resmi lembaga pendidikan, bahasa resmi perhubungan pada tingkat nasional, bahasa media masa. Sebagaimana yang telah dijelaskan bahwa bahasa nasional yang digunakan oleh negara Indonesia adalah bahasa Indonesia yang berfungsi juga sebagai bahasa pengantar dalam pembelajaran serta bahasa resmi pada tingkat nasional.

Sedangkan tujuan pembelajaran bahasa Indonesia secara khusus menitik beratkan pada hasil karya sastra manusia Indonesia agar lebih dihargai sehingga dapat melestarikan sastra Indonesia, dan meningkatkan kemampuan dalam berbahasa. Hal tersebut sesuai dengan Badan Standar Nasional Pendidikan (Susanto,2016,p245) bahwa pembelajaran bahasa Indonesia diarahkan untuk meningkatkan kemampuan peserta didik untuk berkomunikasi dengan bahasa Indonesia dengan baik dan benar,baik secara lisan maupun tulis, serta menumbuhkan apresisasi terhadap hasil karya kesastraan manusia Indonesia.

Peningkatan

kemampuan

berbahasa pada bahasa Indonesia bukan hanya untuk digunakan sebagai alat komunikasi secara lisan ataupun tulisan. Lebih jauh lagi, pembelajaran bahasa Indonesia bertujuan agar peserta didik lebih menghargai karya sastra Indonesia dan dapat melestarikan bahasa Indonesia sebagai bagaian dari budaya negara Indonesia.

Pada kurikulum 2013 pembelajaran Bahasa Indonesia disebut dengan pembelajaran yang berbasis teks. Dengan orientasi baru ini, pembelajaran Bahasa Indonesia terfokus pada berbagai teks yang bisa digunakan dalam kehidupan seharihari. Dapat dipahami bahwa dalam pembelajaran berbasis teks, membutuhkan suplemen pembelajaran yang dibutuhkan untuk mendukung ketuntasan hasil belajar siswa. Selain buku wajib yang disediakan oleh kemendikbud yang merupakan buku panduan baik bagi guru maupun bagi siswa, akan tetapi diperlukan juga buku latihan lain guna meningkatkan semangat belajar siswa.

Lebih lanjut dikatakan bahwa, pembelajaran bahasa Indonesia berbasis teks menjadikan teks sebagai dasar, azas, pangkal, serta tumpuan dalam pembelajaran itu sendiri. Hal senada diungkapkan oleh Abidin (2012) bahwa teks-teks yang disajikan menjadi dasar untuk menumbuhkan karakter bagi siswa. Melalui teks kebahasan dan kesastraan dimasukan sebagai bahan ajar itu sendiri. Dipahami bahwa, dalam pembelajaran berbasis teks tersebut siswa dituntut untuk aktif mengamati, menanya, menalar, mencoba dan mengkomunikasikan hal-hal 
yang berkaitan dengan materi yang akan dipelajari.

Bahan ajar merupakan segala bentuk bahan yang digunakan guna membantu pendidik dalam melaksanakan proses kegiatan belajara mengajar di dalam kelas. Lebih lanjut dikatakan oleh Majid (2012, p173) bahwa dengan bahan ajar, memungkinkan siswa unuk mempelajari suatu kompetensi atan kompetensi dasar secara runtut dan sistematis sehingga secara kuantitatif mampu menguasai semua kompetensi secara utuh dan terpadu. Dapat dipahami bahwa, pemanfaatan bahan ajar dalam pembelajaran bahasa Indonesia bertujuan untuk meningkatkan keterampilan berbahasa siswa sekaligus menanamkan nilai-nilai karakter bangsa yang menjadi tuntutan kurikulum. Mata pelajaran bahasa Indonesia di SD dalam kurikulum 2013 dicirikan dengan pendekatan pembelajaran yang berbasis teks.

Bahan ajar sebagai kompenen dalam kurikulum yang akan disampaikan kepada siswa. Bahan ajar merupakan komponen yang berperan sebagai materi pembelajaran, ketika proses pembelajaran. Materi pembelajaran tersebut disusun dalam silbus guna mempermudah pelaksanaan pembelajaran. Materi pembelajaran terlebih dahulu dikembangkan, sehingga lengkap dan siap digunakan sebagai bahan ajar. Keberhasilan dalam proses pembelajaran dapat ditentukan oleh pendidik yang profesional, input yang baik, serta pemilihan ahan ajar yang tepat dan berkualitas guna tercapainya tujuan pembelajaran itu sendiri.

Dalam realitas pendidikan di lapangan, banyak pendidik yang masih menggunakan bahan ajar yang siap pakai, tinggal beli, instan, tanpa upaya merencanakan, menyiapkan dan menyusun sendiri. Dengan demikian resiko yang didapat adalah bahan ajar yang mereka pakai kurang menarik. Seorang pendidik dituntut kreativitasnya untuk mampu menyusun bahan ajar yang inovatif, variatif, menarik, kontekstual dan sesuai dengan tingkat kebutuhan siswa. Pendidik adalah sebagai orang yang paling paham mengenai hal ini. Maka dari itu, jika bahan ajar dibuat oleh pendidik, pembelajaran akan lebih menarik dan mengesankan bagi siswa.

Berdasarkan studi pendahuluan yang dilakukan oleh peneliti di SDN Dukuh Tengah 1 Ketanggungan Kecamatan Brebes kabupaten Brebes, bahwa guru hanya menggunakan sumber yang berasal dari buku paket yang telah tersedia. Selian itu, buku tersebut belum memenuhi kebutuhan siswa serta belum menyesuaikan dengan karakteristik siswa. Dalam kegiatan belajar mengajar, guru hanya mengarahkan siswa untuk mencatat materi yang dibahas, setelah itu guru memberikan tugas dibagian akhir pada buku paket tersebut.

Bahan ajar yang sesuai untuk dikembangkan adalah bahan ajar yang berbasis pendekatan kontekstual. Peneliti mengembangkan bahan ajar dengan pendekatan kontekstual dikarenakan pendekatan tersebut dianggap tepat digunakan dalam pembelajaran bahasa Indonesia di Sekolah Dasar. Melalui penggunaan pendekatan kontekstual dalam bahan ajar yang dikembangkan maka akan membuat siswa dapat mengaitkan antara materi pelajaran dengan situasi atau keadaan di dunia nyata.

\section{Metode Penelitian}

Penelitian ini menggunakan penelitian research and development menurut Brog \& Gall . Sugiyono (2007: p407) mengemukakan bahwa metode pengembangan adalah metode yang digunakan untuk menghasilkan produk tertentu dan pengujian keefektifan produk tersebut. Lebih lanjut brog and gall (Rachmatullah dan Sumantri, 2018) menyatakan bahwa pada dasarnya penilitian dan pengembangan adalah proses yang digunakan untuk mengembangkan dan memvalidasi produk yang dikembangkan. Pengembangan bahan ajar bahasa Indonesia berbasis kontekstual untuk siswa Sekolah Dasar merupakan penelitian pengembangan yang diarahkan untuk menghasilkan bahan ajar yang telah dikembangkan berdasarkan pola pembelajaran kontekstual. Penelitian ini dilakukan pada siswa kelas lima Sekolah Dasar Negeri Dukuh Tengah 1 
Ketanggungan Kabupaten Brebes Jawa Tengah. Penelitian ini dilakukan dengan mengembangkan bahan ajar secara sistematis. Adapun langkah-langkah dalam pengemabngan bahan ajar ini diantaranya: (1) studi awal, (2) perencanaan, (3) desain produk, dan (4) validitas produk.

\section{Hasil Penelitian}

Rekapitulasi hasil penilaian oleh validator yang diperoleh dari ahli materi dan ahli bahasa pada produk yang telah dikembangkan dalam bentuk bahan ajar dapat dilihat pada tabel bi bawah ini:

\section{Tabel 1: Rekapitulasi Hasil Penilaian} Validator

\begin{tabular}{llr}
\hline No & Aspek Penilaian & \multicolumn{1}{c}{ Skor } \\
\hline 1 & Kelayakan isi & $85,94 \%$ \\
2 & Bahasa dan gambar & $85,71 \%$ \\
3 & Penyajian & $81,25 \%$ \\
4 & Kegrafikan & $87,5 \%$ \\
Rata-rata & $85,1 \%$ \\
\hline
\end{tabular}

Berdasarkan data pada tabel 1 dapat disimpulkan bahwa hasil penilaian dari validator terhadap bahan ajar bahasa indonesia berbasis kontekstual memperoleh skor rata-rata $85,1 \%$ dalam kategori valid. Tes keterbacaan pada bahan ajar bahasa Indonesia bebrbasis kontekstual yang dilakukan pada 30 siswa kelas V di SDN Dukuh Tengah 01 Ketanggunagan Kecamatan Brebers Kabupaten Brebes. Berdasarkan skor, kategori buku bacaan mudah dipahami.

Melihat dari rekapitulasi hasil validasi validator yang memperoleh skor $85,1 \%$ dengan kategori sangat valid dan tes keterbacaan mendapatkan $88 \%$ dengan kategori buku mudah dipahami, produk yang telah dikembangkan dapat dilanjutkan dan digunakan ketika pembelajaran di Sekolah Dasar khususnya di Kelas V.

\section{Kesimpulan}

Berdasarkan hasil penelitian dan pembahasan, dapat disimpulkan bahwa pengembangan produk berupa bahan ajar bahasa Indonesia berbasis kontekstual untuk siswa kelas lima Sekolah Dasar, dikembangkan berdasarkan analisis kebutuhan pendidik dan siswa. Dari hasil analisis kebutuhan, maka prinsip-prinsip pengembangan bahan ajar diformulasikan untuk meningkatkan kemampuan berbahasa berdasarkan kontekstual yang pada umumnya bahan ajar berisi materi yang praktis dan kegiatan pembelajaran yang melibatkan kegiatan praktis serta mendorong siswa untuk memiliki kemampuan berpikir tingkat tinggi.

Produk-produk yang telah dikembangkan telah divalidasi oleh para ahli materi dan ahli bahasa dan tes keterbacaan telah dilakukan pada 30 siswa SDN Dukuh Tengah 01 Ketanggungan Kecamatan Brebers Kabupaten Brebes. Hasil validasi keseluruhan dari kedua ahli tersebut memperoleh persentase $85,1 \%$ dengan kategori sangat valid dan uji keterbacaan memperoleh hasil 88,00. dengan kategori yang mudah dipahami. Berdasarkan kriteria ini, bahan ajar bahasa Indonesia berdasarkan kontekstual cocok untuk digunakan sebagai buku pendamping dalam belajar di kelas lima Sekolah Dasar.

\section{Daftar Pustaka}

Majid abdul. (2012). Perencanaan pembelajaran mengembangkan standar kompetensi guru. Bandung; PT. Remaja Rosdakarya.

R. Rachmadtullah, Z. Ms, and M. S. Sumantri, "Development of computer - based interactive multimedia: study on learning in elementary education," Int. J. Eng. Technol., vol. 7, no. 4, pp. 20352038, 2018.

Chaer, Abdul. (2013). Lingustik Umum. Jakarta : Rineka Cipta

Silvia, (2010). Undang-undang Dasar 1945 \& Amandemennya. Jakarta : Generasi Cerdas

Susanto. Ahmad. (2016). Teori Belajar \& Pembelajaran. Jakarta Pernadamedia Group.

Saleh. Muhammad. (2015). Pengembangan bahan ajar Bahasa Indonesia berbasis kurikulum 2013 yang mengintegrasikan nilai karakter bangsa 
di SMP. Jurnal pendidikan dan pembelajaran, volume 22, nomor 2 .

Abdin. Yunus. (2012). Pembelajaran membaca berbasis pendidikan karakter. Bandung; Refika Aditama. 